\title{
Physicochemical components and antioxidant activity of Sparassis crispa mixture fermented by lactic acid bacteria
}

\author{
Jae-Joon Lee ${ }^{1}$, Hye-Young Son ${ }^{2}$, Young-Min Choi ${ }^{3}, \mathrm{Jae}^{-\mathrm{H} a n} \mathrm{Cho}^{4}$, \\ Jung-Kee Min ${ }^{5}$, Hee-Kyung $\mathrm{Oh}^{5 *}$ \\ ${ }^{1}$ Department of Food and Nutrition, Chosun University, Gwangju 61452, Korea \\ ${ }^{2}$ Severance Biomedical Science Institute, Yonsei University College of Medicine, Seoul 03772, Korea \\ ${ }^{3}$ Department of Animal Sciences, Kyungpook National University, Sangju 37224, Korea \\ ${ }^{4}$ Mushroom Research Division, National Institute of Horticultural and Herbal Science RDA, Eumseong 27709, Korea \\ ${ }^{5}$ Department of Food and Nutrition, Jangan University, Hwaseong 18331, Korea
}

\section{유산균 발효 꽃송이버섯 혼합물의 이화학적 성분과 항산화 활성}

\author{
이재준 ${ }^{1} \cdot{\text { 손혜 } \text { 영 }^{2} \cdot \text { 최영민 }}^{3} \cdot$ 조재한 $^{4} \cdot$ 민정기 $^{5} \cdot$ 오희경 ${ }^{5 *}$ \\ ${ }^{1}$ 조선대학교 식품영양학과, ${ }^{2}$ 연세대학교 의생명과학부, ${ }^{3}$ 경북대학교 축산학과, \\ ${ }^{4}$ 국립원예특작과학원 버섯과, ${ }^{5}$ 장안대학교 식품영양과
}

\begin{abstract}
The objective of this study was to investigate the nutritional composition and antioxidant activity of a mixture of rice bran and bodies of Sparassis crispa fermented with lactic acid bacteria (LAB). LAB-fermented $S$. crispa mixture had higher water, crude lipid and crude ash content than that of $S$. crispa. Insoluble dietary fiber contents of the dried powder of $S$. crispa and LAB-fermented $S$. crispa mixture were $46.13 \%$ and $33.46 \%$, respectively. $\beta$-glucan was higher in dried $S$. crispa $(38.03 \%)$ than in LAB-fermented $S$. crispa mixture (5.44\%). Dried $S$. crispa contained mainly fructose and glucose instead of containing sucrose in LAB-fermented $S$. crispa mixture. No significant differences in the total polyphenol contents were found in between dried $S$. crispa and LAB-fermented $S$. crispa mixture. Total flavonoid content was significantly higher in LAB-fermented $S$. crispa mixture than in dried $S$. crispa. No significant differences were found in the DPPH radical scavenging activity and in the antioxidant index between dried $S$. crispa and LAB-fermented $S$. crispa mixture. Finally, ABTS radical scavenging activity of LAB-fermented $S$. crispa mixture was significantly higher than that of dried $S$. crispa. These results may provide the basic data for future studies for a better understanding of the biological activities of LAB-fermented $S$. crispa mixture.
\end{abstract}

Key words : Sparassis crispa, fermentation, $\beta$-glucan, nutritional composition, antioxidant activity

\section{서 론}

현대 사회에서 급증하는 다양한 질환들은 대부분 염증성 질환에 의해서 유발되고 있는 성격을 가지고 있다. 이들

*Corresponding author. E-mail : hkoh01@hanmail.net Phone : 82-31-299-3063, Fax : 82-31-299-3609

Received 23 March 2016; Revised 10 May 2016; Accepted 6 June 2016

Copyright (c) The Korean Society of Food Preservation. All rights reserved.
질환을 치료하기 위해 의학이 지속적으로 크게 발전은 하고 있지만 암, 치매, 당뇨 등 성인병은 아직도 극복되지 못하고 있으며 이에 따른 치료와 예방을 위해 관련된 생리활성을 갖는 천연식품에 대한 연구가 활발히 진행되고 있다. 곰팡 이에 속하는 버섯은 오랫동안 식용으로 이용되어 왔으며 생리활성에 도움이 되는 항산화 물질이나 질병의 치료에 도움이 되는 항암(1), 항산화(2), 항고혈압(3) 등의 다양한 물질이 발견되고 있어서 기능성 소재로 주목을 받고 있다. 꽃송이버섯(Sparassis crisspa)은 꽃송이버섯과 꽃송이버 섯속에 속하는 식용버섯으로 자실체는 $10 ~ 25 \mathrm{~cm}$ 크기의 
꽃양배추 모양을 닮았으며, 전체적으로 담황색 또는 흰색 을 나타내고 있다(4). 한국, 일본, 중국, 북미, 유럽 등에 주로 분포하며, 여름에서 가을까지 침엽수의 뿌리 근처 줄 기나 그루터기에 뭉쳐서 자생하는 것으로 알려져 있다(5). 꽃송이버섯은 $\beta-1,3-D-g l u c a n$ 의 함량이 다른 버섯에 비해 월등히 높아 면역증강과 항암효과가 있는 것으로 알려지면 서 식용뿐만 아니라 약용으로도 인정받고 있다(6). 현재까 지 꽃송이버섯은 주로 일본 업체에서 인공재배 및 제품 개발을 주도하고 있으나, 국내에서는 꽃송이버섯 대량생산 체계가 확산되지 못하고 있는 실정이다. 한편 국내 일반농 가에서 꽃송이버섯을 실용적으로 재배할 수 있는 방법은 개발되고 있지만, 다른 버섯과는 달리 꽃송이버섯 균사는 생장 속도가 현저히 느리고, 국내 재배환경에 맞는 우량품 종이 개발되지 못해 일본품종에 의존하고 있고 상태이다. 국내업체에서도 꽃송이버섯 자실체의 분말 또는 추출물을 이용한 건강기능식품과 가공식품을 제조하여 유통되고 있 으나 꽃송이버섯을 부원료로 첨가한 기능성식품 제조에 관한 연구(7)는 아직까지 미미한 실정이다.

최근 들어 유산균 발효를 이용한 천연물 발효공정은 천 연소재 추출물의 활성 성분 및 생리활성의 증가를 극대화시 킬 수 있는 공정으로 많이 알려져 있다(8). 인삼열매(9), 블루베리(10), 복분자(11), 부추(12) 등 다양한 식품소재를 사람에게 유익한 미생물인 유산균으로 발효시켜 천연물과 미생물 상호 간의 상승효과에 의한 생리활성 효능 증가는 물론, 관능적 품질을 향상시킨 발효식품을 개발하려는 연 구가 활발하게 진행되고 있다(13). 발효공정에서 사용되는 유산균은 항산화 효능(14), 면역 증진 및 항암효과 $(15,16)$ 등의 예방 효능을 가지고 있으며, 다양한 발효식품 또는 생균제의 형태로 섭취되어 우리 몸에 유익한 작용을 주는 건강기능성 식품소재로 보고되었다 $(17,18)$.

따라서 본 연구는 꽃송이버섯 자실체를 미강에 첨가하여 유산균으로 발효한 꽃송이버섯 혼합물과 꽃송이버섯 자실 체의 일반성분, 식이섬유소 및 $\beta$-glucan 함량을 비교 분석하 였다. 또한 항산화 활성을 검증하여 유산균 발효 꽃송이버 섯 혼합물의 건강기능식품 산업의 이용 가능성을 제시하고 자 한다.

\section{재료 및 방법}

\section{실험재료}

본 실험에서 사용된 꽃송이버섯 자실체는 청송지역 꽃송 이버섯 농장에서 2015년 재배하여 열풍 건조한 것을 제공 받아 본 실험에 사용하였다. 시료는 먼저 분쇄기(FM-909W, Hanil Co., Sejong, Korea)로 분쇄한 다음 autoclave (HB-506-4, Hanbaek Science Co., Bucheon, Korea)를 이용하 여 $121^{\circ} \mathrm{C}$ 에서 15 분간 멸균 시킨 후 실험에 사용하였다. 또한
본 실험에 사용한 미강은 2014년 경기도 강화도에서 생산 된 친환경 벼를 2015년 강화마니산미곡처리장(DY-3000R, Yesung Co., Ltd., Daegu, Korea)에서 도정하여 제공받아 사용하였다. Lactobacillus acidophilus, Bifidobacterium spp., Streptococcus thermophilus으로 구성 되어진 유산균제품 (ABT-5, CHR- HANSEN, Hoersholm, Denmark)과 우유 (Seoul Dairy Co., Korea)는 시중에 구입하여 사용하였다.

\section{유산균 발효 꽃송이버섯 혼합물}

유산균 발효 꽃송이버섯 혼합물은 아래와 같은 재료 배 합비로 제조하였다. 즉 미강 $910 \mathrm{~g}$ 에 꽃송이버섯 자실체 분말 $80 \mathrm{~g}$ 을 넣고 고루 섞어주었다. 우유 $10 \mathrm{~g}$ 을 넣고 반죽한 후 전기찜기(Mach steamer, Dachang Co., Seoul, Korea)에서 $102^{\circ} \mathrm{C}, 40$ 분 동안 증자하였다. 온도를 $38^{\circ} \mathrm{C}$ 으로 낮춘 후 유산균 제품 $500 \mathrm{~mL}$ 를 넣고 5 10분간 알맞게 반죽 한 다음 $37^{\circ} \mathrm{C}$ 에서 48 시간 발효하였다. 발효가 완료되면, 오븐시트 지에 일정량씩 고른 두께 $(7 \times 7 \times 7 \mathrm{~mm})$ 로 펼쳐서 $45^{\circ} \mathrm{C}$ 에서 24시간 건조기(SYA-150, Daehan Co., Gwangju, Korea)에서 건조한 후 분쇄하여 실험에 사용하였다.

\section{추출물 제조}

꽃송이버섯과 유산균 발효 꽃송이버섯 혼합물을 이용하 여 메탄올 추출물을 제조하였다. 건조된 시료 $100 \mathrm{~g}$ 당 methanol 1,500 mL을 첨가한 후 환류냉각관을 부착한 $65^{\circ} \mathrm{C}$ 의 heating mantle(Mtops ms-265, Seoul, Korea)에서 3시간씩 3회 추출한 다음 Whatman filter paper(No.2)로 여과하였으 며, 여액을 $40^{\circ} \mathrm{C}$ 수욕 상에서 rotary vacuum evaporator (EYELA VACUUM NVC-1100, Tokyo, Japan)로 용매를 제 거하고 감압 - 농축한 후 동결건조하고 시료의 산화를 방지 하기 위해 $-70^{\circ} \mathrm{C}$ 에 냉동 보관하였다.

\section{일반성분 분석}

버섯 시료의 일반성분은 식품공전의 일반시험법에 따라 분석(19)하였다. 수분 함량은 $105^{\circ} \mathrm{C}$ 상압가열건조법으로, 조회분 함량은 $550^{\circ} \mathrm{C}$ 전기회화로를 이용한 직접회화법으 로, 조지방 함량은 Soxhlet 추출법, 조단백질 함량은 자동질 소 증류장치를 이용한 micro-Kjeldahl법으로 각각 분석하였 다. 탄수화물은 100 에서 수분, 조단백질, 조지방 및 조회분 을 제외한 값으로 나타내었다.

\section{식이섬유소 분석}

버섯 시료의 수용성 식이섬유소, 불용성 식이섬유소 및 총 식이섬유소 함량은 $\mathrm{AOAC}$ 법에 의하여 분석(20)하였다. 시료 $1 \mathrm{~g}$ 에 MES/TRIS 완충용액(0.05 M MES, $0.05 \mathrm{M}$ TRIS, $24^{\circ} \mathrm{C}$ 에서 $\left.\mathrm{pH} 8.2\right) 40 \mathrm{~mL}$ 를 가하고 교반하여 충분히 분산시 킨 후 내열성 a-amylase $50 \mu \mathrm{L}$ 를 가하였다. $95^{\circ} \mathrm{C}$ water bath 에서 40 분간 교반한 후 온도를 $60^{\circ} \mathrm{C}$ 로 낮추고 protease 100 
$\mu \mathrm{L}$ 를 넣고 30 분간 반응하였다. 그 후 $0.561 \mathrm{~N} \mathrm{HCl}$ 용액 $5 \mathrm{~mL}$ 를 가하여 $\mathrm{pH}$ 를 4.0 4.7로 조정하고 amyloglucosidase $300 \mu \mathrm{L}$ 를 넣고 30 분간 교반하였다. 미리 규조토를 넣어 항량을 구해놓은 유리여과기에 효소분해 한 시료를 여과한 후 잔사는 $70^{\circ} \mathrm{C}$ 의 물 $10 \mathrm{~mL}$ 로 2 회 씻은 후 세척액은 여액에 합치고 잔사는 다시 $90 \%$ ethanol과 acetone의 순으로 각각 $15 \mathrm{~mL}$ 씩 2회 세척한 후 무게를 측정하였다. 이 잔사 양에서 잔사의 회분량과 단백질량을 감하여 불용성 식이섬유 함량 을 구하였다. 앞서 얻은 여액에는 $90 \%$ ethanol $200 \mathrm{~mL}$ 를 가하고 $60^{\circ} \mathrm{C}$ 에서 1 시간 동안 정치하여 침전물을 형성시키 고 규조토를 넣어 항량시킨 유리여과기로 여과한 후 잔사는 $90 \%$ ethanol과 acetone의 순으로 각각 $15 \mathrm{~mL}$ 로 2회 세척한 후 무게를 측정하였다. 이 잔사 양에서 잔사의 회분량과 단백질량을 감하여 수용성 식이섬유 함량을 구하였다. 이 렇게 측정된 불용성 식이섬유 함량과 수용성 식이섬유 함량 을 합하여 총 식이섬유 함량을 구하였다.

\section{$\beta$-glucan 함량 분석}

버섯 시료의 $\beta$-glucan 함량은 Megazyme kit(Mushroom and Yeast $\beta$-glucan assay procedure K-YBGL)를 이용하여 측정하였다. 시료 $100 \mathrm{mg}$ 에 $37 \% \mathrm{HCl} 1.5 \mathrm{~mL}$ 를 넣고 $30^{\circ} \mathrm{C}$ water bath에서 45 분간 교반한 후 3 차 증류수 $10 \mathrm{~mL}$ 를 가하 고 $100^{\circ} \mathrm{C}$ water bath에서 다시 2 시간 교반하였다. 이 반응액 을 상온으로 식힌 후 $2 \mathrm{~N} \mathrm{KOH} 10 \mathrm{~mL}$ 를 가하여 혼합하였다. 이 혼합물에 $0.2 \mathrm{M}$ sodium acetate buffer(pH 5.0)를 가하여 $100 \mathrm{~mL}$ 로 정용한 후 원심분리 $(1,500 \times \mathrm{g}, 10$ 분 $)$ 하여 상등액 을 얻었다. 상등액 $0.1 \mathrm{~mL}$ 에 exo-1,3- $\beta$-glucanase $(20 \mathrm{U} / \mathrm{mL})$ $+\beta$-glucosidase $(4 \mathrm{U} / \mathrm{mL})$ 용액 $0.1 \mathrm{~mL}$ 를 가하고, $40^{\circ} \mathrm{C}$ water bath에서 60분간 반응시켰다. 이 반응액에 $\mathrm{GOPOD(glucose}$ oxidase/peroxidase, Megazyme) 시약 $3 \mathrm{~mL}$ 를 넣고 $40^{\circ} \mathrm{C}$ 에서 20 분간 반응시킨 후 $510 \mathrm{~nm}$ 파장에서 흡광도를 측정하여 total glucan 함량의 계산에 사용하였다. 또한 시료 $100 \mathrm{mg}$ 에 $2 \mathrm{~N} \mathrm{KOH} 2 \mathrm{~mL}$ 를 넣고, ice/water bath에서 20분간 교반하였 다. 이 반응액에 $1.2 \mathrm{M}$ sodium acetate buffer(pH 3.8$) 8 \mathrm{~mL}$ 와 amyloglucosidase $(1630 \mathrm{U} / \mathrm{mL})+$ invertase $(500 \mathrm{U} / \mathrm{mL})$ 용액 $0.2 \mathrm{~mL}$ 를 가하고 $40^{\circ} \mathrm{C}$ water bath에서 30 분간 교반한 후 원심분리 $(1,500 \times \mathrm{g}, 10$ 분 $)$ 하여 상등액을 얻었다. 상등액 0.1 $\mathrm{mL}$ 에 $0.2 \mathrm{M}$ sodium acetate buffer(pH 5.0) $0.1 \mathrm{~mL}$ 와 GOPOD 시약 $3 \mathrm{~mL}$ 를 넣고 $40^{\circ} \mathrm{C}$ 에서 20 분간 반응시킨 후 $510 \mathrm{~nm}$ 파장에서 흡광도를 측정하여 a-glucan 함량의 계산에 사용 하였다. 측정된 total glucan과 a-glucan의 흡광도는 표준물 질인 glucose 용액 $(1 \mathrm{mg} / \mathrm{mL})$ 을 $\mathrm{GOPOD}$ 시약과 반응시킨 반응액의 흡광도를 이용하여 각각 함량 $(\mathrm{g} / 100 \mathrm{~g})$ 값으로 계산하였다. $\beta$-glucan 함량은 total glucan 함량에서 a-glucan 함량을 빼준 값으로 계산하였다.

\section{유리당 분석}

유리당 분석은 다음과 같이 실시하였다. 건조된 시료를
분쇄하여 칭량하여 $50 \% \mathrm{EtOH} 15 \mathrm{~mL}$ 와 혼합하였다. $80^{\circ} \mathrm{C}$ 항온수조에서 20 분간 sonication 한 후 3 분간 얼음에서 냉각 시켰다. Shaker를 사용하여 15 분간 $2,000 \mathrm{rpm}$ 에서 혼합한 후 $3,000 \mathrm{rpm}$ 에서 10 분간 원심분리 하였다. $0.2 \mu \mathrm{m}$ syring filter로 여과 후 HPLC 분석시료로 사용하였다. 시료는 0.2 um syring filterMillipore, Billerica, MA, USA)로 여과하여 고속 액체 크로마토크래피(Shiseido Nanospace SI-2, Shiseido, Tokyo, Japan)를 이용하여 분석하였다. 이동상으 로는 $90 \%$ acetonitrile를 사용하였고, 유속은 $0.4 \mathrm{~mL} / \mathrm{min}$ 으로 하였으며 column 온도는 $60^{\circ} \mathrm{C}$ 로 설정하였다. Shodex RI-101 detector(Japan)로 검출하였으며, Unison UK-Amino column ( $250 \times 3 \mathrm{~mm}, 3 \mu \mathrm{m}$, Imtakt Co., Kyoto, Japan)을 사용 하였다. Injection volumn은 $4 \mu \mathrm{L}$ 를 주입하였다.

\section{총 polyphenol 함량}

총 polyphenol 함량은 Folin-Denis 방법(21)에 따라 측정 하였다. Test tube에 시료 $1 \mathrm{~mL}$ 과 Folin reagent $2 \mathrm{~mL}$ 을 넣은 후 실온에서 3 분간 정치한 다음 $10 \% \mathrm{Na}_{2} \mathrm{CO}_{3} 2 \mathrm{~mL}$ 을 첨가하였고, 이를 혼합한 후 $30^{\circ} \mathrm{C}$ 에서 40 분간 정치하였으 며, UV-visible spectrophotometer(UV-1601PC, Shimadzu, Kyoto, Japan)를 사용하여 $760 \mathrm{~nm}$ 에서 흡광도를 측정하였 다. 표준곡선은 tannic acid(Sigma-Aldrich Co., St. Louis., $\mathrm{MO}, \mathrm{USA})$ 의 검량선에 의하여 함량을 검출하였다.

\section{총 flavonoid 함량}

총 flavonoid 함량은 Davis법의 방법(22)을 변형하여 측정 하였다. 시료 $1 \mathrm{~mL}$ 에 diethylene glycol $2 \mathrm{~mL}$ 을 첨가한 다음 $1 \mathrm{~N} \mathrm{NaOH} 20 \mu \mathrm{L}$ 을 넣고, $37^{\circ} \mathrm{C}$ water bath에서 1 시간 동안 반응시킨 후 UV-spectrophotometer(UV-1601PC, Shimadzu, Kyoto, Japan)로 $420 \mathrm{~nm}$ 에서 흡광도를 측정하였다. 표준곡 선은 rutin hydrate(Sigma-Aldrich Co., St. Louis, MO, USA) 의 검량선에 의하여 함량을 검출하였다.

\section{DPPH radical 소거활성}

DPPH radical 소거능은 Blois의 방법(23)을 변형하여 측 정하였다. 버섯 시료 추출물 $1 \mathrm{~mL}$ 과 $0.2 \mathrm{mM}$ 2,2-diphenyl1-picrylhydrazyl(DPPH) $1 \mathrm{~mL}$ 을 test tube에 취한 후 혼합하 여 $37^{\circ} \mathrm{C}$ 에서 30 분간 반응시켜 UV-spectrophotometer(UV1601PC, Shimadzu, Kyoto, Japan)를 사용하여 $517 \mathrm{~nm}$ 에서 흡광도를 측정하였다. 라디칼 소거능(\%)은 (1-시료첨가구 의 흡광도/무첨가구의 흡광도) $\times 100$ 에 의하여 활성도를 산 출하였다.

\section{ABTS radical 소거활성}

ABTS radical의 소거활성은 Roberta 등의 방법(24)으로 측정하였다. $7.4 \mathrm{mM} \mathrm{2,2'-azino-bis(3-ethylbenzthiazoline-}$ 6-sulfonic acid; ABTS)와 $2.6 \mathrm{mM}$ potassium persulphate를 
하루 동안 암소에 방치하여 ABTS 양이온을 형성시킨 후 이 용액을 $735 \mathrm{~nm}$ 에서 흡광도 값이 $0.9 \pm 0.02$ 이 나오도록 buffer로 희석하여 사용하였다. 흡광도를 맞춘 ABTS 용액 $0.5 \mathrm{~mL}$ 에 시료 $0.5 \mathrm{~mL}$ 를 가하여 $37^{\circ} \mathrm{C}$ 에서 30 분간 반응시키 고, $735 \mathrm{~nm}$ 에서 흡광도를 측정하였으며, $\mathrm{ABTS}$ 라디칼 소거 활성(\%)은 (1-시료첨가구의 흡광도/무첨가구의 흡광 도 $\times 100$ 에 의하여 활성을 산출하였다.

\section{항산화지수}

항산화지수(antioxidant index, $\mathrm{AI}$ )는 Rancimat(Metrohm model 679, Herisan, Switzerland)을 이용하여 측정하는 방법 으로 Joo와 $\mathrm{Kim}$ 의 방법(25)에 의하여 실시하였다. 흰 민들 레 에탄올 추출물에 포함된 용매를 완전히 제거한 후 추출 물의 함량이 $1,000 \mathrm{ppm}$ 이 되도록 soybean oil(Sigma Co., USA)에 첨가하고, 초음파기기(Ultrasonic processor, UCX$750, \mathrm{CT}, \mathrm{USA})$ 를 이용하여 유기 용매 추출물과 유지가 잘 혼합되도록 하였다. Rancimat의 측정 조건은 시료 $3.0 \mathrm{~g}$ 를 반응 용기에 취하고 증류수 $70 \mathrm{~mL}$ 를 측정용기에 넣은 후 $110^{\circ} \mathrm{C}$ 에서 air flow rate $20 \mathrm{~L} / \mathrm{hr}$ 로 하여 산화안정성을 비교하 였다. 항산화지수는 추출물을 첨가한 실험군의 유도시간을 추출물을 첨가하지 않은 대조군의 유도시간으로 나눈 값을 구하였다.

\section{통계처리}

실험에서 얻어진 결과의 통계적 유의성은 SPSS 통계 Package를 이용하여 실험군당 평균 \pm 표준편차로 표시하였 고, 각 군당 3 개의 시료를 사용하여 실험은 3 회 반복 시행하 였으며, t-test와 Tukey's test에 의하여 각 실험군의 평균치 간의 유의성을 검정하였다.

\section{결과 및 고찰}

\section{일반성분 함량}

꽃송이버섯 자실체의 원물과 유산균 발효 꽃송이버섯 혼합물의 일반성분 분석 결과는 Table 2 와 같다. 꽃송이버

$\underline{\text { Table 1. Analytical conditions for analysis of sugars with HPLC }}$

\begin{tabular}{lc}
\hline \multicolumn{1}{c}{ Contents } & Condition \\
\hline HPLC & Shiseido Nanospace SI-2 (Shiseido, Tokyo, Japan) \\
Column & Unison UK-Amino $(250 \times 3 \mathrm{~mm}, 3 \mu \mathrm{m}$, Imtakt Co., \\
Kyoto, Japan $)$ \\
Mobile phase & $90 \%$ acetonitrile \\
Detector & Shodex RI-101 (Japan) \\
Column & $60^{\circ} \mathrm{C}$ \\
temperature & $0.4 \mathrm{~mL} / \mathrm{min}$ \\
Flow rate & $4 \mu \mathrm{L}$ \\
Injection volume & \\
\hline
\end{tabular}

섯 분말은 탄수화물 $75.11 \%$, 조단백질 $13.11 \%$, 수분 $4.21 \%$, 조지방 $3.86 \%$, 조회분 $3.71 \%$ 순이었으며, 유산균 발효 꽃송 이버섯 혼합물은 탄수화물 $51.28 \%$, 조지방 $22.18 \%$, 조단백 질 $11.19 \%$, 조회분 $9.94 \%$, 수분 $5.41 \%$ 순이었다. 유산균 발효 꽃송이버섯 혼합물이 꽃송이버섯 분말에 비하여 수 분, 조지방 및 조회분 함량은 유의적으로 높게 나타났다 $(\mathrm{p}<0.05)$.

Table 2. Approximate compositions of fruit body of Sparasis crispa and LAB-fermented Sparassis crispa

$(\%)$

\begin{tabular}{lcc}
\hline \multicolumn{1}{c}{ Composition } & Sparassis crispa & LAB-fermented Sparassis crispa \\
\hline Moisture & $4.21 \pm 0.01^{\mathrm{b} 2}$ & $5.41 \pm 0.08^{\mathrm{a}}$ \\
Crude lipid & $3.86 \pm 0.12^{\mathrm{b}}$ & $22.18 \pm 0.11^{\mathrm{a}}$ \\
Crude protein & $13.11 \pm 0.23^{\mathrm{a}}$ & $11.19 \pm 0.63^{\mathrm{b}}$ \\
Crude ash & $3.71 \pm 0.10^{\mathrm{b}}$ & $9.94 \pm 0.06^{\mathrm{a}}$ \\
Carbohydrate $^{1)}$ & $75.11 \pm 0.16 \mathrm{a}$ & $51.28 \pm 0.78^{\mathrm{b}}$ \\
\hline
\end{tabular}

${ }^{1)} 100$-(sum of moisture, crude protein, crude lipid and crude ash contents).

${ }^{2)}$ All values are expressed as mean $\pm S D$ of triplicate determinations. Means within each row by the same letter are not significantly different $(\mathrm{p}<0.05)$.

\section{식이섬유소 조성 및 $\beta$-glucan 함량}

꽃송이버섯 자실체의 원물과 유산균 발효 꽃송이버섯 혼합물의 식이섬유소 조성과 $\beta$-glucan 함량을 비교한 결과 는 Table 3과 같다. 꽃송이버섯 원물의 총 식이섬유소, 불용 성식이섬유소 및 수용성 식이섬유소의 함량은 각각 51.71 , 46.13 및 5.59\%를 보였으며, 유산균 발효 꽃송이버섯 혼합 물은 $34.95,33.46$ 및 $1.48 \%$ 로 나타났다. 꽃송이버섯 원물의 총 식이섬유소 중 $89.21 \%$ 가 불용성 식이섬유소로 구성되어 있고, 유산균 발효 꽃송이버섯 혼합물의 불용성 식이섬유 소 함량은 총 식이섬유소의 $95.74 \%$ 를 차지하였다. 이에 비해 수용성 식이섬유의 함량은 꽃송이버섯 분말과 유산균 발효 꽃송이버섯 혼합물에서 $1.5 \sim 5.6 \mathrm{~g} / 100 \mathrm{~g}$ 수준으로 매우 낮았다. $\operatorname{Lim}$ 등(26)은 꽃송이버섯 원물의 총 식이섬유소 중 불용성 식이섬유소 함량이 $96.0 \%$ 로 구성되어 있는 것으 로 보고되어 본 연구에서의 꽃송이버섯 원물 내 불용성 식이섬유소 함량이 다소 낮은 것으로 나타났다. 한편 꽃송 이버섯 자실체 분말 $100 \%$ 를 이용한 유산균 발효물에서의 불용성 식이섬유소가 총 식이섬유소의 $96.67 \%$ 를 차지하는 것으로 보고되어(26) 본 연구에서의 꽃송이버섯 자실체 분 말 8\%을 미강에 첨가한 유산균 발효 혼합물과 유사한 경향 을 보였으며, 이는 꽃송이버섯을 $8 \%$ 로 첨가하였더라도 미 강 내 함유되어 있는 불용성 식이섬유소 함량으로 인해 높게 나타난 것으로 사료된다

본 연구에서 측정된 버섯 원물의 $\beta$-glucan 함량은 $38.03 \%$ 으로 나타났다. 이는 일본에서 재배된 꽃송이버섯 자실체 는 약 $40 \mathrm{~g} / 100 \mathrm{~g}$ 의 함량을 갖고 있다는 보고(27)와 본 연구 
결과를 비교했을 때 유사한 것으로 나타났다. 유산균 발효 꽃송이버섯 혼합물의 $\beta$-glucan 함량은 $5.44 \%$ 으로 버섯 원 물의 $\beta$-glucan 함량에 비하여 유의적으로 낮게 나타났다.

Table 3. Dietary fiber composition and $\beta$-glucan content of fruit body of Sparassis crispa and LAB-fermented Sparassis crispa

$(\%)$

\begin{tabular}{lcc}
\hline \multicolumn{1}{c}{ Composition } & Sparassis crispa & LAB-fermented Sparassis crispa \\
\hline Total dietary fiber & $51.71 \pm 1.45^{\mathrm{a} 1)}$ & $34.95 \pm 0.16^{\mathrm{b}}$ \\
Soluble dietary fiber & $5.59 \pm 0.57^{\mathrm{a}}$ & $1.48 \pm 0.57^{\mathrm{b}}$ \\
Insoluble dietary fiber & $46.13 \pm 0.60^{\mathrm{a}}$ & $33.46 \pm 0.49^{\mathrm{b}}$ \\
B-glucan & $38.03 \pm 1.75^{\mathrm{a}}$ & $5.44 \pm 0.36^{\mathrm{b}}$ \\
\hline
\end{tabular}

${ }^{1)}$ All values are expressed as mean $\pm \mathrm{SD}$ of triplicate determinations. Means within each row by the same letter are not significantly different $(p<0.05)$.

\section{유리당 함량}

꽃송이버섯 자실체의 원물과 유산균 발효 꽃송이버섯 혼합물의 유리당 함량은 Table 4와 같다. 꽃송이버섯 원물 에는 유리당 중 glucose $4.96 \%$ 와 fructose $1.77 \%$ 만 함유하고 있으며, 유산균 발효 꽃송이버섯 혼합물은 sucrose만 5.17\% 를 함유하고 있는 것으로 분석되었다. 전체적으로 이당류 중 lactose 및 maltose는 검출되지 않았고 유산균 발효 꽃송 이버섯 혼합물과 달리 버섯 원물에서는 sucrose가 검출되지 않았다. Cho 등(28)은 식용 및 약용버섯의 단당류 및 이당류 함량을 분석한 연구결과에서 꽃송이버섯의 단당류는 glucose와 fructose으로 각각 함량이 $8.95 \mathrm{~g} / \mathrm{L}$ 와 $2.23 \mathrm{~g} / \mathrm{L}$ 으로 보고되어 본 연구 결과의 꽃송이버섯에 비해 다소 높게 나타났다. 또한, 꽃송이버섯과 찔레버섯을 제외하고 29 종 류의 버섯류에서 이당류가 검출되지 않았다고 보고하였으 며, 꽃송이버섯에서 lactose 함량은 $3.38 \mathrm{~g} / \mathrm{L}$ 이라고 보고하 여(27) 본 연구결과와 차이가 있었다. 이는 꽃송이버섯의 산지, 품종, 재배 지역 등에 따라 유리당 함량에 차이가 있음을 시사한다. 본 연구에서의 유산균 발효 꽃송이버섯 혼합물에서 sucrose가 검출 되었으며, 이러한 결과는 톳 추 출액을 유산균으로 발효시킨 결과, 환원당의 급속한 감소 가 있었다는 Song 등(29)의 연구결과와 유사하였다. 이는

Table 4. Free sugar contents of fruit body of Sparassis crispa and LAB-fermented Sparassis crispa

(\%)

\begin{tabular}{ccc}
\hline Composition & Sparassis crispa fruit & LAB-fermented Sparassis crispa \\
\hline Glucose & $4.96 \pm 0.15^{1)}$ & $\mathrm{ND}^{2)}$ \\
Fructose & $1.77 \pm 0.50$ & $\mathrm{ND}$ \\
Sucrose & $\mathrm{ND}$ & $5.17 \pm 0.24$ \\
Lactose & $\mathrm{ND}$ & $\mathrm{ND}$ \\
Maltose & $\mathrm{ND}$ & $\mathrm{ND}$ \\
\hline
\end{tabular}

${ }^{1)}$ All values are expressed as mean $\pm \mathrm{SD}$ of triplicate determinations.

${ }^{2)} \mathrm{ND}$, Not detected.
미생물이 발효 중 환원당을 탄소원으로 이용하였기 때문인 것으로 사료된다.

\section{총 polyphenol 및 총 flavonoid 함량}

꽃송이버섯 자실체의 원물과 유산균 발효 꽃송이버섯 혼합물의 총 polyphenol 및 총 flavonoid 함량은 Table 5 에 나타났다. 총 polyphenol 함량은 꽃송이버섯 원물과 유산균 발효 꽃송이버섯 혼합물에서 유의적인 차이는 나타나지 않았다. 총 flavonoid 함량은 유산균 발효 꽃송이버섯 혼합 물에서 꽃송이버섯 원물에 비하여 유의적으로 높게 나타났 다(p<0.05). Seo 등(30)은 구지뽕 열매를 유산균을 이용하여 발효하였을 경우 총 polyphenol 함량이 증가하였으며, Song 등(31)은 생더덕 추출물의 초기 총 polyphenol 함량이 0.54 $\mathrm{mg} / 100 \mathrm{~g}$ 이었으나, 유산균 발효 후 $2.79 \mathrm{mg} / 100 \mathrm{~g}$ 으로 약 5 배 정도 증가하였다고 보고하였다. 본 연구에서는 꽃송이 버섯 원물과 유산균 발효 꽃송이버섯 혼합물의 총 polyphenol 함량 차이는 크게 없는 것으로 조사되었으며, 이는 유산균 발효에 의해 꽃송이버섯 $8 \%$ 혼합물에서 항산 화 활성을 가지는 것으로 알려진 polyphenol 화합물이 생성 된 것이라고 판단된다. 한편, Lee와 Hong(32)은 블루베리를 유산균을 이용하여 발효한 다음 총 flavonoid 함량이 무발효 블루베리에 비해 높은 함량을 나타내었다고 보고하여 본 연구결과와 유사한 것으로 나타났다. 이는 유산균 발효에 의해 유익한 항산화 물질이 생성된 것으로 사료되어 진다.

Table 5. Total polyphenol and flavonoid contents of fruit body of Sparassis crispa and LAB-fermented Sparassis crispa

\begin{tabular}{lcc}
\hline \multicolumn{1}{c}{ Sample $^{1)}$} & $\begin{array}{c}\text { Total polyphenol } \\
(\mathrm{mg} / \mathrm{g} \mathrm{DW})\end{array}$ & $\begin{array}{c}\text { Total flavonoid } \\
(\mathrm{mg} / \mathrm{g} \mathrm{DW})\end{array}$ \\
\hline Sparassis crispa & $133.64 \pm 0.96^{\mathrm{a})}$ & $5.21 \pm 0.26^{\mathrm{b}}$ \\
LAB-fermented Sparassis crispa & $124.72 \pm 3.68^{\mathrm{a}}$ & $19.03 \pm 0.15^{\mathrm{a}}$ \\
\hline
\end{tabular}

${ }^{11)}$ The concentration of all test samples was $2,000 \mathrm{ppm}(2 \mathrm{mg} / \mathrm{mL})$.

${ }^{2)}$ Tannic acid equivalent.

${ }^{3)}$ Rutin equivalent.

${ }^{4)}$ All values are expressed as mean \pm SD of triplicate determinations. Means within each row by the same letter are not significantly different $(p<0.05)$.

\section{항산화활성}

꽃송이버섯 자실체의 원물과 유산균 발효 꽃송이버섯 혼합물의 DPPH 및 ABTS radical 소거활성은 Table 6과 같다. DPPH radical 소거능은 꽃송이버섯 원물과 유산균 발효 꽃송이버섯 혼합물에서 유의적인 차이는 나타나지 않았으나, 대조구인 비타민 C에 비해서는 유의적으로 낮은 DPPH radical 소거능을 나타났다(p<0.05). ABTS radical 소 거능은 유산균 발효 꽃송이버섯 혼합물이 꽃송이버섯 원물 에 비해 유의적으로 높은 것으로 나타났으며, 대조구인 비 타민 C와는 유의적인 차이를 보이지 않았다. Lee 등(10)은 블루베리 유산균 발효물에서 DPPH 및 superoxide radical 소거활성이 무발효 블루베리에 비해 증가한다고 보고하였 
으며, Lee 등(9)은 유산균 발효를 통한 인삼열매의 라디칼 환원력에 대한 연구에서 유산균 발효 인삼열매 추출물은 무발효 추출물에 비해 항산화 활성이 증가하는 것으로 확인 하였다. 인체 내의 free radical은 지질, 단백질 등과 반응 생체의 노화를 촉진할 수 있는 물질로 free radical을 제거할 수 있는 천연물질에 대한 연구가 활발히 진행되고 있으며, 이러한 free radical을 환원시키거나 상쇄시키는 능력이 크 면 높은 항산화 활성 및 활성산소를 비롯한 다른 radical에 대하여 소거 활성을 기대할 수 있다. 본 연구에서는 radical 의 환원력을 $\mathrm{DPPH}$ 와 $\mathrm{ABTS}$ 방법으로 측정하였으며, 이들 방법 모두 radical의 환원력을 측정하는 실험으로 원리는 비슷하지만 약간의 차이가 있다. ABTS radical 소거능은 극성과 비극성 시료의 소거활성을 모두 확인할 수 있으나, $\mathrm{DPPH}$ 는 비극성 물질에서만 확인할 수 있다는 점에서 차이 가 있다. 또한 DPPH는 free radical, ABTS는 cation radical에 반응하여 기질의 특성이 서로 다르므로 $\mathrm{ABTS}$ 유리기 소거 법이 DPPH 유리기 소거법보다 적용 범위가 넓다(33). 이와 같은 방법을 이용하여 유산균 발효 꽃송이버섯 혼합물의 항산화 활성을 측정한 결과, DPPH와 ABTS radical 소거활 성에 모두 효능이 있는 것으로 나타났으며, 이는 유산균 발효 후 총 polyphenol과 flavonoid 함량 증가로 인해 항산화 활성이 증가하는 것으로 사료된다.

Table 6. DPPH radical scavenging activity and ABTS radical scavenging activity of fruit body of Sparassis crispa and LAB-fermented Sparassis crispa

(\%)

\begin{tabular}{lcc}
\hline \multicolumn{1}{c}{ Sample $^{1 \mathrm{l}}$} & $\begin{array}{c}\text { DPPH radical } \\
\text { scavenging activity }\end{array}$ & $\begin{array}{c}\text { ABTS radical } \\
\text { scavenging activity }\end{array}$ \\
\hline Sparassis crispa & $71.99 \pm 1.65^{\mathrm{b2}}$ & $88.32 \pm 0.52^{\mathrm{b}}$ \\
LAB-fermented Sparassis crispa & $79.8 \pm 0.33^{\mathrm{b}}$ & $92.42 \pm 0.94^{\mathrm{a}}$ \\
Vitamin C & $91.14 \pm 0.82^{\mathrm{a}}$ & $93.75 \pm 0.75^{\mathrm{a}}$ \\
\hline
\end{tabular}

${ }^{1)}$ The concentration of all test samples was $2,000 \mathrm{ppm}(2 \mathrm{mg} / \mathrm{mL})$.

${ }^{2)}$ All values are expressed as mean $\pm S D$ of triplicate determinations. Means within each column by the same letter are not significantly different $(\mathrm{p}<0.05)$.

\section{항산화 지수}

꽃송이버섯 자실체의 원물과 유산균 발효 꽃송이버섯 혼합물의 유지 산화 억제효과를 알아보기 위하여 Rancimat 으로 측정한 항산화지수는 Table 7과 같다. 양성 대조군으로 사용한 천연항산화제인 비타민 $\mathrm{C}$ 의 항산화지수는 15.32 로 가장 높게 나타났고, 꽃송이버섯 원물과 유산균 발효 꽃송 이버섯 혼합물은 유의적인 차이가 나타나지 않았다. 꽃송 이버섯 원물과 유산균 발효 꽃송이버섯 혼합물의 항산화지 수는 각각 1.73 과 1.86 으로 통계적으로 유사한 경향을 보였 고, 대조구인 비타민 $\mathrm{C}$ 에 비해서는 낮았으나 시료를 첨가하 지 않은 음성대조군의 1.00 보다는 높게 나타나 꽃송이버섯 원물과 유산균 발효 꽃송이버섯 혼합물의 soybean oil에
대한 산화 억제효과가 있는 것을 확인하였다 $(\mathrm{p}<0.05)$. 이와 같이 유산균 발효 꽃송이버섯 혼합물의 항산화 효과를 Racimate으로 측정한 항산화지수는 DPPH 및 ABTS radiacl 소거능의 결과와 유사하게 꽃송이버섯 원물과 유의적인 차이를 나타나지 않았다. 상기의 결과들을 종합할 때 유산 균 발효 꽃송이버섯 혼합물이 항산화효과에 기여하는 것으 로 여겨지며, 보다 정확한 결과를 얻기 위한 차후 연구가 필요할 것으로 사료된다.

Table 7. Antioxidant index of fruit body of Sparassis crispa and LAB-fermented Sparassis crispa

\begin{tabular}{lcc}
\hline \multicolumn{1}{c}{ Sample } & $\mathrm{IP}^{2)}$ & $\mathrm{AI}^{3)}$ \\
\hline Control $^{1)}$ & $7.01 \pm 0.15^{4(5)}$ & $1.00^{\mathrm{c}}$ \\
Sparassis crispa & $12.13 \pm 0.82^{\mathrm{b}}$ & $1.73 \pm 0.02^{\mathrm{b}}$ \\
LAB-fermented Sparassis crispa & $13.02 \pm 0.21^{\mathrm{b}}$ & $1.86 \pm 0.03^{\mathrm{b}}$ \\
Vitamin C & $15.32 \pm 0.84^{\mathrm{a}}$ & $2.19 \pm 0.01^{\mathrm{a}}$ \\
\hline
\end{tabular}

${ }^{1)}$ Control, Soybean oil without Sparasis cripa ethanol extracts.

${ }^{2)}$ Induction period (IP) of oil was determined by test of Rancimat at $110^{\circ} \mathrm{C}$.

${ }^{3)}$ Antioxidant index (AI) was expressed as IP of oil containing sample/IP of soybean oil.

${ }^{4)}$ All values are expressed as mean $\pm \mathrm{SE}$ of triplicate determinations.

${ }^{5}$ Means within each column by the same letter are not significantly different $(\mathrm{p}<0.05)$.

\section{요 약}

본 연구는 꽃송이버섯 원물과 꽃송이버섯 $8 \%$ 첨가하여 유산균으로 발효한 꽃송이버섯 혼합물의 이화학적 특성 및 항산화 활성을 비교 조사하였다. 유산균 발효 꽃송이버 섯 혼합물의 수분, 조지방 및 조회분 함량은 버섯 원물에 비해 유의적으로 높게 나타났다( $\mathrm{p}<0.05)$. 꽃송이버섯원물 과 유산균 발효 꽃송이버섯 혼합물의 총 식이섬유소 중 불용성 식이섬유소가 각각 $89.21 \%$ 와 $95.74 \%$ 를 차지하였 다. 꽃송이버섯 원물의 $\beta$-glucan 함량은 $38.03 \%$ 으로 유산균 발효 꽃송이버섯 혼합물의 $\beta$-glucan 함량 $5.44 \%$ 에 비해 유의적으로 높게 나타났다. 꽃송이버섯 원물에는 유리당 중 glucose와 fructose만 함유하고 있으며, 유산균 발효 꽃송 이버섯 혼합물은 sucrose만을 함유하였다. 총 polyphenol 함량은 꽃송이버섯 원물과 유산균 발효 꽃송이버섯 혼합물 에서 유의적인 차이는 나타나지 않았다. 총 flavonoid 함량 은 유산균 발효 꽃송이버섯 혼합물이 꽃송이버섯 원물에 비하여 유의적으로 높게 나타났다( $\mathrm{p}<0.05)$. DDPH radical 소거능은 꽃송이버섯 원물과 발효 꽃송이버섯 혼합물에서 유의적인 차이는 나타나지 않았으나, 대조군인 비타민 C에 비해서는 유의적으로 낮은 DDPH radical 소거능을 나타냈 다(p<0.05). ABTS radical 소거능은 유산균 발효 꽃송이 버 섯 혼합물이 꽃송이 버섯 원물에 비해 유의적으로 높은 것으로 나타났으며, 대조군인 비타민 $\mathrm{C}$ 와는 유의적인 차이 
를 보이지 않았다(p<0.05). 꽃송이버섯 원물과 유산균 발효 꽃송이버섯 혼합물의 항산화지수도 비슷한 경향을 보였고, 대조군인 비타민 C에 비해서는 낮았으나, 시료를 첨가하지 않는 음성대조군 보다는 높게 나타났다. 따라서 유산균 발 효 꽃송이버섯 혼합물은 항산화 작용에 긍정적인 영향을 미칠 수 있는 천연소재로서 산업적 활용이 가능할 수 있을 것이다.

\section{References}

1. Lee YS, Kim JB, Shin SR, Kim NW (2006) Analysis of nutritional components of Lepista nuda. Korean J Food Preserv, 13, 375-381

2. Lee SK, Yoo YJ, Kim CS (1994) Studies on the chemical components in Ganoderma lucidum Korean J Food Sci Technol, 21, 890-894

3. Kim BK, Shin GG, Jeon BS, Cha JY (2001) Cholesterol-lowering effect of mushrooms powder in hyperlipidemic rats. Korean J Food Sci Nutr. 30, 510-515

4. Oh DS (2003) Studies on the optimal cultural media and conditions for mycelial growth of Sparassis crispa (wulf.) fr. MS Thesis, Chonnam National University, Gwangju, Korea, p 33

5. Oh DS, Park JM, Park H, Ka KH, Chun WJ (2009) Site characteristics and vegetation structure of the habitat of cauliflower mushroom (Sparassis crispa). Kor J Mycol, 37, 33-40

6. Harada T, Miura N, Adachi Y, Nakajima M, Yadomae T, Ohno N (2002) Effect of SCG, 1,3- $\beta$-D-glucan from Sparassis crispa on the hematopoietic response in cyclophosphamide induced leukopenic mice. Biol Pharm Bull, 25, 931-939

7. Lim CW, Kang KK, Yoo YB, Kim BH, Bae SH (2012) Dietary fiber and $\beta$-glucan contents of Sparassis crispa fruit fermented with Lactobacillus brevis and Monascus pilosus. J Korean Soc Food Sci Nutr, 41, 1740-1746

8. Park KY (2012) Increased health functionality of fermented foods. Food Indus Nutr, 17, 1-8

9. Jeon JM, Choi SK, Kim YJ, Jnag SJ, Cheon JW, Lee HS (2011) Antioxidant and antiaging effect of ginseng berry extract fermented by lactic acid bacteria. J Soc Cosmet Scientists Korea, 37, 75-81

10. Lee DH, Hong JH (2015) Physicochemical properties and storage stability of blueberry fermented by lactic acid bacteria. Korean J Food Preserv, 22, 796-803

11. Lee JB, Bae JS, Son IK, Jeon CP, Lee EH, Joo WH,
Kwon GS (2014) Antioxidant and ACE Inhibiting activities of sugared-buchu (Allium ampeloprasum L. var. porum J. Gay) fermented with lactic acid bacteria. J Life Sci, 24, 671-676

12. Lee YJ, Yoon BR, Kim DB, Kim MD, Lee DW, Kim JK, Lee OH (2012) Antioxidant activity of fermented wild grass extracts. Korean J Food Nutr, 25, 407-412

13. Kim MJ, Yang SA, Park JH, Kim HI, Lee SP (2011) Quality characteristics and anti-proliferative effects of dropwort extracts fermented with fructooligosaccharides on HepG2 cells. Korean J Food Sci Technol, 43, 432-437

14. Jeon JM, Choi SK, Kim YJ, Jang SJ, Cheon JW, Lee HS (2011) Antioxidant and antiaging effect of ginseng berry extract fermented by lactic acid bacteria J Soc Cosmet Scientists Korea, 37, 75-81

15. Kim SY, Shin KS, Lee H (2004) Immunopotentiating activities of cellular components of Lactobacillus brevis FSB-1. J Korean Soc Food Sci Nutr, 33, 1552-1559

16. Park SH, Kim YA, Lee DK, Lee SJ, Chung MJ, Kang BY, Kim KJ, Ha NJ (2007) Antibacterial activity and macrophage activation of lactic acid bacteria. J Environ Toxicol, 22, 287-297

17. Park KB, Oh SH (2005) Production and characterization of GABA rice yogurt. Food Sci Biotechnol, 14, 518-522

18. Park JC, Cha JY, Lee CH, Doh ES, Kang IH, Cho YS (2009) Biological activities and chemical characteristics of Monascus fermented Korean red ginseng. J Life Sci, 19, 1553-1561

19. AOAC (1990) Official methods of analysis. 15th. ed., Association of official analytical chemists, Washington DC, USA, p 5-7

20. AOAC (2000) Official methods of analysis. 16th ed., Association of Official Analytical Chemists, Washington DC, USA, $\mathrm{p}$ 7-10

21. Folin O, Denis W (1912) On phosphotungstic phosphomolybdic compounds as color regents. J Biol Chem, 12, 239-249

22. Chae SK, Kang GS, Ma SJ, Bang KW, Oh MW, Oh SH (2002) Standard food analysis. Jigu-moonwhasa, Paju, Korea, p 381-382

23. Blois MS (1958) Antioxidant determinations by the use of a stable free radical. Nature, 181, 1199-1200

24. Roberta R, Nicoletta P, Anna P, Ananth P, Min Y, Catherine RE (1999) Antioxidant activity applying an improved ABTS radical cation decolorization assay. Free Radical Bio Med, 26, 1231-1237

25. Joo KJ, Kim JJ (2002) Oxidative stability and flavor 
compounds of sesame oils blended with vegetable oils. Korean J Food Sci Technol, 34, 984-991

26. Lim CW, Kang KK, Yoo YB, Kim BH, Bae SH (2012) Dietary fiber and $\beta$-glucan contents of Sparassis crispa fruit fermented with Lactobacillus brevis and Monascus pilosus. J Korean Soc Food Sci Nutr, 41, 1740-1746

27. Yamamoto K, Kimura T, Sugitachi A, Matsuura N (2009) Anti-angiogenic and anti-metastatic effects of $\beta$ -1,3-D-glucan purified from Hanabiratake, Sparassis crispa. Biol Pharm Bull, 32, 259-263

28. Cho JH, Park HS, Han JG, Lee GH, Sung GH, Jhune CS (2014) Comparative analysis of total sugar and sugar alcohol contents of the fruiting bodies in edible and medicinal mushrooms. J Mushrooms, 12, 316-323

29. Song HS, Kim HK, Min HO, Choi JD, Kim YM (2011) Change of physicochemical and sensory properties of Hizikia fusiformis water extract by the fermentation of lactic acid bacteria. Korean J Fish Aquat Sci, 44, 104-110

30. Seo MJ, Kang BW, Park JU, Kim MJ, Lee HH, Kim NH, Kim KH, Rhu EJ, Jeong YK (2013) Effect of fermented Cudrania tricuspidata fruit extracts on the generation of the cytokines in mouse spleen cells. J Life Sci, 23, 682-688

31. Song SW, Park SJ, Seong DH, Park DS, Kim SS, Dou JY, Ahn JH, Yoon WB, Lee HY (2009) Biological activities in the extract of fermented Codonopsis lanceolata. J Korean Soc Food Sci Nutr, 38, 983-988

32. Lee DH, Hong JH (2015) Physicochemical properties and storage stability of blueberry fermented by lactic acid bacteria. Korean J Food Preserv, 22, 796-803

33. Cho AR, Park KW, Kim KM, Kim SY, Han JJ (2014) Influence of roasting conditions on the antioxidant characteristics of Colombian coffee (Coffea arabica L.) beans. J Food Biochem, 38, 271-280 